\title{
溶接のシュミレーションに関する 国家プロジェクト*
}

野城

清**

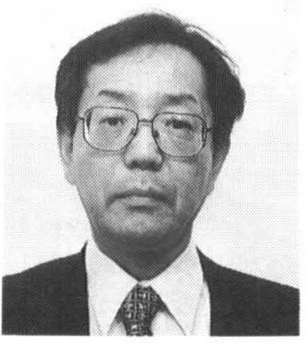

National Project for Welding Simulation*

by Kiyoshi NOGI**

キーワード：国家プロジェクト, 溶接技術, シュミレーション

\section{1. は じめに}

溶接技術は過去半世紀にわたりめざましい発展を遂 げ，世間では確立された技術のように思われているが, 溶接現象は種々の要素が複雑に絡み合った非平衡現象で あるために, これまでは熟練労働者の経験と勘に頼った 部分が多く，解明すべき問題が多くある，特に我が国に おいては本格的な高路化社会を迎之豊富な経験と高度の 技能を有する溶接技術者の不足が既に産業界において大 きな問題になっていること，さらには阪神・淡路大震災 や原子力発電所のトラブルで溶接部に起因するものが多 くあることからも分かるように, 産業界から高度溶接技 術の確立が強く望まれてきた。

一方, 昨今のコンピュータの演算能力・データ容量の 飛躍的な向上により, 総合的・体系的なシミュレーショ ンプログラムの構築が可能になってきており, 経験的な 技術開発を基本としてきた溶接分野においてもシミュ レーション技術を確立させる環境が整いつつある.

上記の状況のもとで, 平成 12 年度から通産省工業技 術院の重要地域技術研究開発「溶接技術の高度化による 高効率・高信頼性溶接技術の開発」のプロジェクトがス タートした. 本プロジェクトは期間 5 年間 (平成 12 年 度 平成 16 年度）で予算総額約 20 億円の規模であり, 大阪大学接合科学研究所が中心となり, 大阪大学大学院 工学研究科, 株式会社神戸製鋼所, 川崎重工業株式会社 等が共同して溶接の高効率化，エネルギー使用量削減を 図ることが可能な高効率・高信頼性の溶接技術の開発を 目的としている.

\section{2. プロジェクトの具体的目的と目標}

本プロジェクトの目標は, 溶接技術の信頼性を高め, 溶接作業の効率向上を可能とする溶接技術の開発であ ク，実際に産業界で活用される高度ではあるが，使いや

\footnotetext{
*原稿受付 平成 12 年 12 月 22 日

**正員大阪大学接合科学研究所 (プロシェクト委員長) Member, Joining and Welding Research Institute, Osaka Univ.
}

すいシステムの構築である.

具体的には，パソコンを用いて操作可能な下記の 3 つ の相互に関連したシミュレーションモデルを開発すると 同時に，参加企業による企業化を目標とする.

(1)溶接プロセスシミュレーション

局所熱平衡を仮定しないアークプラズマモデルを作成 し，これを組み込んだ溶接プールにおける対流熱輸送の シミュレーションモデルを開発する。併せて, 多層溶接 やパイプの円周溶接等を対象とした MAG およびTIG 溶接プロセスのシミュレーションモデルを開発する.

(2)溶接部組織プロセスシミュレーションモデル

$450 \mathrm{MPa}$ 級鋼に対して従来末開発であるアシキュラー フェライトの生成モデルを組み込んだ溶接部組織シミュ レーションモデルを開発する。ささらに，溶接部の機械的 特性を組織から予測可能な技術開発を行い, モデル化す る.また $950 \mathrm{MPa}$ 級鋼については従来確定されていない 特性向上組織の構造を解明する.

(3)溶接変形予测シミュレーションモデル

パソコンで計算可能な面外変形を含む溶接変形予測プ ログラムを開発する。具体的には面外変形を含む溶接変 形を精度良く予測可能にする。 また残留応力については 計算精度を維持した上で, 計算速度を既存のプログラム より大幅に速める.

これら目標を達成するために，溶接現象の精緻な観察 を通して, 溶融池内の湯流れと溶け込み現象の解明, 溶 接欠陥の生成機構の解明を行うと同時に, シミュレー ションに必要な溶接金属の溶融状態の表面張力, 密度, 粘度, さらには固体及び溶融状態の熱伝導率等の物性值 測定を実施することになっている。

\section{3. 終わりに}

幸いにも初年度は関係する研究者各位の努力で研究は 順調に推移しているが, 本プロジエクトは 5 年間を予定 しており，最終的に十分な成果を挙げ，産業界に貢献で きるように溶接関係者各位の叱咤激励をお願いする次第 である。 